\title{
The Role of Effective Governance in Determining the Relationship Between Muslims' Religiosity and Their Income
}

\author{
SIDRAH KHALIL* \& HODA MANSOUR ${ }^{1}$
}

\begin{abstract}
Most of the studies which examine the effect of religiosity on income in the literature have found the relationship to be negative among Muslims and non-Muslims. The waves of migration of religious Muslims to non-Muslim majority countries have raised concerns about the future of the economic growth of such hosting countries. This paper introduces the government as a variable that interacts with religiosity and explains this complex link. In this study, we use panel data from the World Values Survey and the World Bank Governance Indicators for 68 countries over 14 different years from 1996 to 2014 to test how governance explain the religiosity-income link among Muslims. The study found evidence that countries with higher government effectiveness levels experience a lower negative impact of religiosity on income. Results show that the negative size shrinks with better governance until it becomes statistically insignificant when countries are at a very high government effectiveness level.
\end{abstract}

Keywords: Governance, Religiosity, Government Effectiveness, Muslims, Income.

Economics of religion is a relatively recent field that flourished with the revolution in the statistical techniques used for either collecting or analyzing surveys data (Iyer 2016). This branch studies how economics affect religion, how religion affects economics, and the integrality between them (Welch \& Mueller, 2001). The mainstream finding and evidence is that religion negatively predicts income and vice versa. However, in such very subjective topics, two points must be put into consideration. Firstly, practicing religions - like any other social activity - may be seen as a cost to the society but may have other indirect benefits. Secondly, results of empirical studies do not necessarily support or oppose religions; ultimately, there is a distinction between the belief, how believers perform, and what they were meant to believe in. What we can't deny is that religion is a very old social component and it impacts the behavior of believers in number of ways (Schoenfield 1993). Furthermore, the rise and fall of the power of any religion is a continued historical event. For instance, Islam had a golden age between the 8th and the 14th century when most Muslims' ruled land witnessed the highest economic development, spread of arts, science and innovation of all nations (Bobrick 2012). Contrarily, in recent years, Islam is even questioned to be valid. In fact, this religion is the fastest growing religion on earth, and most of the top relatively poor countries are Muslim majority ones. This might implicitly mean that the world is moving towards more Muslims and less economic growth. The level of religiosity among Muslims is accused to be the driving factor behind this economic lag. This argument has some opposing facts; Muslims of the United States - for example are mainly immigrants or children of immigrants (Bier 2016) and they have equal or higher economic status and education compared to any average American, but it is not a similar case in Europe (Nowrasteh 2016). The majority of Muslims who claim to be religious live in developing or

${ }^{1}$ Sidrah Khalil*, Ph. D. Candidate, Department of Economics, Faculty of Economics and Political Science, Cairo University, EGYPT. Email: skhalil3@emich.edu; Hoda Mansour, Ph. D. Assoc. Professor, College of Business Administration, University of Business and Technology, Ar-Rawdah, 2343521361 Jeddah, SAUDI ARABIA. E.mail: h.mansour@ubt.edu.sa

$$
\text { https://doi.org/10.24035/ijit.20.2021.217 }
$$


underdeveloped countries where religion becomes more of a habit rather than a deep faith; Guiso et. al. (2003) confirm. As seen in Figure (1), the six governance indicators of the World Bank are presented and showing a significant gap between the average estimates of all world countries estimates and Islamic countries/majority- Muslim countries.

In line with that, this study tests whether developing or underdeveloped countries - with their relatively weak governments and poor institutional quality environments - have an active role in shaping a negative perception in the mind of the believers. This perception might lead religious Muslims to adopt behaviors that lowers their income levels and deters economic growth compared to others living in better institutional qualities with the same level of religiosity. This study adds the government as an interaction and control for potential determinants of income such as Education.

Figure (1): Average of Government Indicators' Estimates for the year 2018

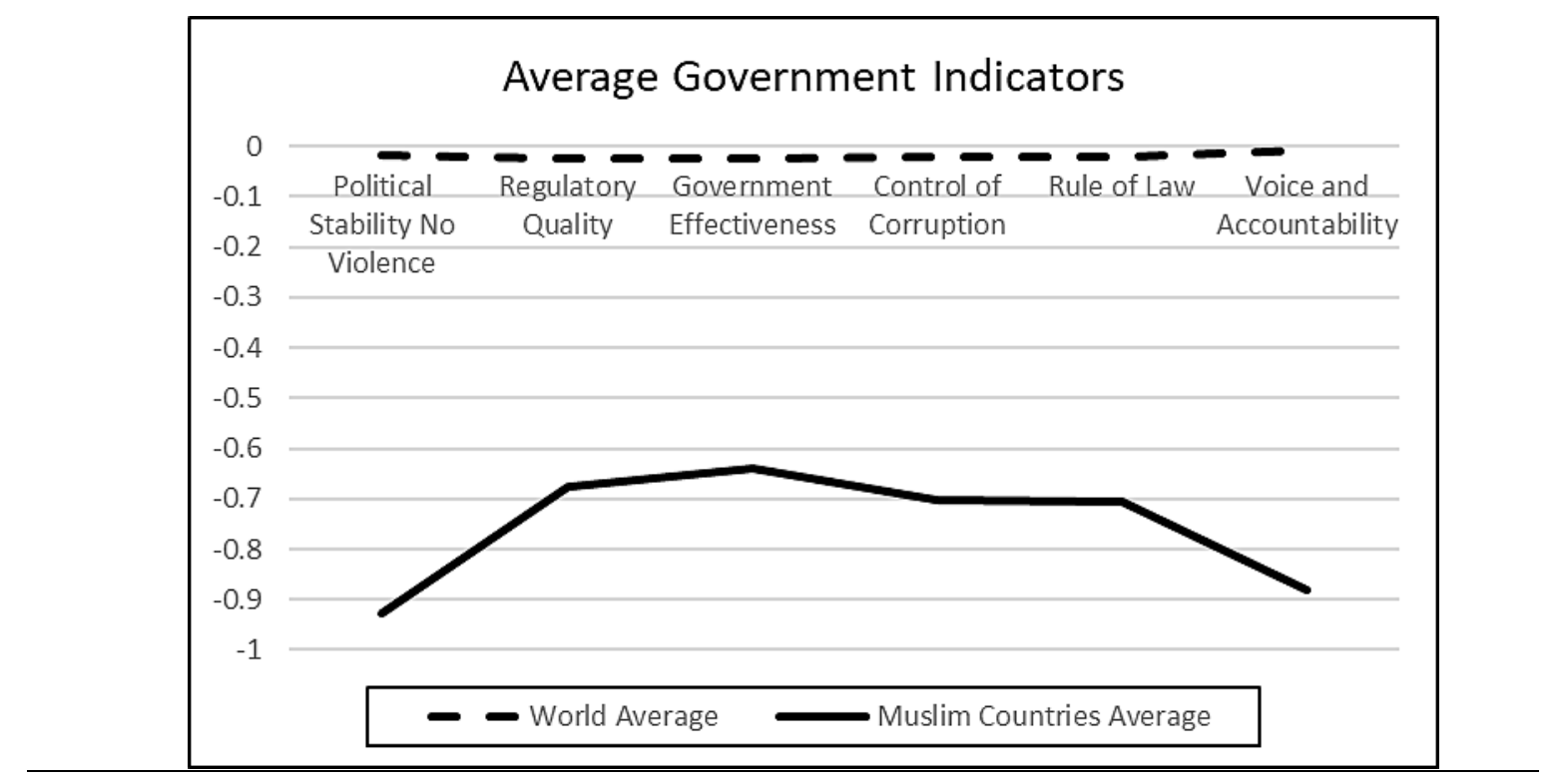

World Average - 2018

Muslim Countries Average - 2018

Political Stability No

Violence

$-0.018693194$

$-0.926828674$

Regulatory Quality

$-0.024944108$

$-0.67430844$

Government Effectiveness

$-0.024931643$

$-0.637990333$

Control of Corruption

$-0.022238531$

$-0.701694905$

Rule of Law

$-0.020943934$

$-0.707123956$

Voice and Accountability

$-0.006133518$

$-0.880788477$

Source: World Governance Indicators - World Bank Database (govdata360.worldbank.org

\section{Literature Review}

Most of the relatively recent studies which integrate religion with economics rely heavily on surveys and data of personal behavior as discussed by Iaanaccone (1998), Welch \& Mueller (2001) and Iyer (2016). Religion, in general, has an effect on the behavior of individuals (Schoenfield,1993) and number of studies linked religion with income. Lipford \& Robert (2003) investigated state level data and found that membership in religious organizations decreases the level of per capita income.

https://doi.org/10.24035/ijit.20.2021.217 
McCleary \& Barro (2006) studied the reverse impact of income on religiosity and supported the mainstream argument that income decreases religiosity. Other studies like Keister \& Lisa (2008) estimated the effect of religious affiliation on wealth ownership among conservative protestants and showed that those who were brought up and continued being conservative protestants experienced low wealth accumulation. On the same line, Becker et. al. (2013) found church attendance in Germany to strongly negatively determine income using historical data between 1886 and 1911. Herzer et. al. (2017) used historical data between 1930 and 1990 to test the effect of church attendance on income and found that the relationship goes both ways; religiosity negatively affects income and higher income was also negatively impacting religiosity. Religion was also found by some papers to trigger behaviors that are bad for economic growth; religious individuals are risk averse (Noussair 2013), which Hilary \& Hui (2009) argued as well, and concluded that firms within religious counties have lower rate of investment and growth.

Some papers have contradicting findings. Those papers do not estimate the effect of religiosity on income but on behaviors that should increase income. For instance, Luigi et. al. (2003) and Guiso et. al. (2003) provided enough evidence to argue that religious beliefs are associated with better economic behaviors. However, Mccleary \& Barro (2003) found that religious "beliefs" predict behaviors which determine higher per capita income and growth while religious "practicing" did not. On one hand saving rates are lower among believers compared to non-believers, but, on the other hand, saving propensity is higher among believers than non-believers (Ma et. al. 2018). On example of the indirect positive effects of practicing religion was discussed by Campante et. al. (2015) who studied the effect of religious "practices" and reported that fasting longer negatively affects output in Muslim countries, however, it increases their subjective well-being and happiness levels. Added to that, a study done by Joshanloo (2018) provided evidence that income satisfaction become less predictive among people believing in religions or other meanings of life. Regarding ethics, Kirchamaier et. al. (2018) showed that individuals who are more attached to their religion do not accept behaviors considered unethical and they are more willing to volunteer, which in turn increases social capital. Vitell \& Paolillo (2003) also discussed ethical and unethical markets and found religiosity to indirectly predict consumers ethical behaviors. Health impacts were also argued by an old study done by Martin (1984) who showed that religiosity prevents suicidal actions. Bowen et. al. (2006) suggests that high importance of religion calms psychiatric symptoms by reducing stress.

Another approach which researchers follow is to try to judge whether religions are good for the economy by differentiating between the effects of each of them. Naveed \& Wang (2018) suggested that religion determine income inequalities; Islam and Judaism inhibits income inequality while Christianity and Buddhism had an opposite effect. However, Petrikova (2019) found Muslims to have more "altruistic" approach regarding their view towards foreign policy, while followers of other religions had negative views. Hillman \& Potrafke (2018) found Protestantism to predict higher economic freedom, while Islam did not, and Catholicism was found to be in between. Another paper by Achi et. al. (2010) showed how religion in general predicts poverty but found that Muslims, protestants or other Christians were more likely to be poor compared to Catholics. In a study published in 2018, Yusof et. al. tested the relationship between religiosity and individual economic achievement in Indonesia and concluded that the relationship is positive using the World Values Survey. Using the same survey, Ali \& Hassan (2019) tested the impact of religiosity on multidimensional poverty in 52 countries and found that higher religiosity levels triggers lower multidimensional poverty results.

While the literature is full of theories and findings, it is rare to find an academic justification that religious beliefs and practices are the reason driving poor economic performance or blaming a religion for the economic deterioration of a region or a whole country, except for Islam which is a religion debated to be triggering a challenging economic situation; for instance, a theoretical paper https://doi.org/10.24035/ijit.20.2021.217 
published by Iyer \& Sriya (2016) concluded that following Islamic rules is the reason behind the "economic backwardness" happened in some countries. The conflicting nature between religion, the government, and politics is ancient but is recently scientifically examined by researchers. Zuckerman et. al. (2018) found evidence among countries - and also among states - that good governance predicts lower levels of religiousness; in other words, if the public have the government they will not need the god. However, in our paper we argue that the performance of the government predicts the "level" and "quality" of the belief.

As discussed in the introduction, Muslims are living out in different countries in the world and are found with their same level of stickiness to religion, but with higher average income levels. Norris \& Inglehart (2012) empirically showed that Muslims who immigrate to the west eventually absorb the hosting country's attitudes. For instance, Furia \& Russell (2008) argue that hostility of eastern cultures to western countries is not predicted by social or religious beliefs but by recent political actions of western countries. These findings support our argument that it more likely to be the effect of the environment where those Muslims are living in which ultimately shape a more depressed view of Islam that inhibit economic growth. Albertsen \& de Soysa (2018) provided evidence to support the idea of "neutrality of the religion" upon what is happening in the Middle East and concluded that it's a parallel war of oil wealth rather than Muslim dominance; "the Middle East and North Africa region seems to matter more than Islam".

\section{Data \& Methods}

\section{Conceptual Background}

As discussed in the literature review, there are contradicting findings among researchers; religion is once seen as a booster to economic growth and sometimes the opposite. However, the mainstream argument is that religiosity negatively affects income. Researchers had also compared religions to each other in terms of their effect either on income or on attitudes that increase economic growth. The level of religiosity among Muslims has been accused of being the reason behind the lack of development in many countries. However, our argument is that religious Muslims living in better countries perform as good as their peers in a society. Therefore, the association of religiosity and income among Muslims show up because of other governance factors, which if kept constant, results would change or at least be less severe.

In this paper we argue that better governance is associated with the level of religiosity and could also predict the quality of it; it is more likely to be the effect of the atmosphere where those Muslims are living within which ultimately shapes a more depressed view of Islam.

In this study we rely on two main claims. Firstly, the more religious Muslims a country has the lower is the average income level of all Muslims living in that country. Secondly, on average, countries with worse governments have higher percentages of religious Muslims. It could be that people living in poverty, unhappiness, and worse living conditions foresee religion as "the hope" for a better after life, and the god as "the saver". It might also serve as a remedy for calmness and adaptation to survive such bad conditions. Worse governance means higher religiosity, and higher religiosity means lower income. The bright side of the story is that if we expect that higher religiosity decreases income in condition of bad governance, we should expect better performance under better institutional qualities.

In order to control for this governance effect, we include an interaction variable between the government and religiosity. The other main variable to control for is education. The data set used has developed, developing and underdeveloped countries. In this case education is the best controller to differentiate between income levels. we predict that education has a positive effect on income. The other variable which we expect that it will have a positive effect on income is marital status. Muslims

https://doi.org/10.24035/ijit.20.2021.217 
are mostly encouraged to get married and the majority of the relationships between men and women are under the marriage umbrella. Thus, the other control variable which we include is being married.

In this study we mainly focus on the government effectiveness indicator reported by the world bank. The world bank has 6 main indicators; control of corruption, rule of law, government effectiveness, rule quality, political stability, and voice and accountability.

While freedom, inclusion, justice, and ethics are mainly what the five other indicators reflect, the only indicator that evaluate the services provided in the society is "government effectiveness". The five other indicators are very important, but they are not "providing" something that directly form the physical living condition.

These indicators are very popular; however, they have been criticized by many researchers. Langbein \& Knack (2010) did a factor analysis study and concluded that these six measures are ultimately measuring the same one concept. According to the world bank, "The government effectiveness indicator captures the quality of public services, the quality of the civil service and the degree of its independence from political pressures, the quality of policy formulation and implementation, and the credibility of the government's commitment to such policies."

\section{Data Description \& Statistics}

This study is done on longitudinal data retrieved from the World Values Survey (WVS) Data is selected for only Muslims, from both sexes of 18 years or above, and is collapsed by the mean to 114 observations from 68 unique countries over 14 different years. The time period covered is from 1996 to 2014. Data is collapsed from 44,966 interviewed Muslims. In addition, estimates from the World Bank Worldwide Governance Indicators ${ }^{2}$ for the same time period is used. Table (1) provides a description of the variables used with definitions and measurements, and table (2) provides summary statistics.

Table (1): Variables Names, Definitions \& Units of Measurements

\begin{tabular}{|c|c|}
\hline Variable name & Description and unit of measurement \\
\hline Income & $\begin{array}{l}\text { Countries average of self-reported income levels of individuals from } 1 \text { (low) to } 10 \\
\text { (high). }\end{array}$ \\
\hline Education & $\begin{array}{l}\text { Countries average of highest education level attained collapsed from positive integers } \\
\text { from } 0 \text { (no education ) to } 8 \text { (higher education). }\end{array}$ \\
\hline Married & $\begin{array}{l}\text { Countries married percent collapsed from recoded integer values of either } 1 \text { (married) } \\
\text { or } 0 \text { (otherwise) }\end{array}$ \\
\hline Religious_Or_Not & $\begin{array}{l}\text { Countries average percent of religious respondents collapsed from answers to are } \\
\text { you: a religious person (1) or Not a religious person (0) }\end{array}$ \\
\hline Regulatory_Quality & $\begin{array}{l}\text { Countries averages of annual estimates of "Regulatory Quality" in units of a standard } \\
\text { normal distribution. }\end{array}$ \\
\hline Rule_of_Law & $\begin{array}{l}\text { Countries averages of annual estimates of "Rule of Law" in units of a standard normal } \\
\text { distribution. }\end{array}$ \\
\hline Voice_Accountability & $\begin{array}{l}\text { Countries averages of annual estimates of "Voice and Accountability" in units of a } \\
\text { standard normal distribution. }\end{array}$ \\
\hline Politi & $\begin{array}{l}\text { Countries averages of annual estimates of "Political Stability and Absence of } \\
\text { Violence/Terrorism" in units of a standard normal distribution. }\end{array}$ \\
\hline
\end{tabular}

Government_Effectivness

Countries averages of annual estimates of "Government Effectiveness" in units of a standard normal distribution.

https://doi.org/10.24035/ijit.20.2021.217 
Control_Corruption $\begin{aligned} & \text { Countries averages of annual esti } \\ & \text { standard normal distribution. }\end{aligned}$

Table (2): Summary Statistics of Dependent and Independent Variables

\begin{tabular}{lcccc}
\hline Variable Name & Mean & St. Deviation & Min & Max \\
\hline Income & 4.640163 & 1.353604 & 1 & 10 \\
Married & .6565427 & .211153 & 0 & 1 \\
Education & 4.55115 & 1.531205 & 0 & 8 \\
Religious or Not & .8172993 & .2244813 & 0 & 1 \\
Regulatory Quality & .2689534 & 1.037091 & -2.120511 & 2.057507 \\
Rule_of_Law & .159199 & 1.102755 & -1.828362 & 1.963109 \\
Voice_Accountability & .1246727 & 1.015555 & -2.124431 & 1.687097 \\
Political_Stability & -.1345634 & 1.039607 & -3.180798 & 1.595862 \\
Government_Effectiveness & .2978764 & 1.061253 & -1.718666 & 2.166091 \\
Control_Corruption & .1810072 & 1.182551 & -1.564978 & 2.376838 \\
\hline
\end{tabular}

As shown in table (2), the data set has higher percentage of married individuals. The mean age is late thirties with middle levels of education and income. As expected, the majority of the sample consider themselves as religious. The only indicator that has a negative mean among the countries is Political_Stability. Variance inflation factors have shown no evidence of multicollinearity between those variables in each model, however, this study has some limitations; data from other countries are available but with inconsistent measures of religiosity so we dropped them, data of governance indicators start from 1996 so we had to drop any earlier waves, and there are some wide gaps in years for some countries but smaller in others, which creates inconsistency and under representation of years and countries.

\section{Model Specification}

This is a pooled cross-sectional study. In this study we use country and time fixed effects model to estimate the effect of religiosity on income levels among Muslims under different governance levels using the following equation:

Income $_{i t}=\beta o+\beta_{1}$ Education $_{i t}+\beta_{2}$ Married $_{i t}+\beta_{3}$ Religous_Or_Not $_{i t}+\beta_{4}$ (Government $_{-}$ Indicator) ${ }_{i t}+\beta_{5}$ (Religious_Or_Not ${ }_{i t} X$ (Government Indicator) ${ }_{i t}+\theta_{\mathrm{i}}+\theta_{t}+\mathrm{u}_{i t}$

In this model, Income is the dependent variable which ranges from 1 (representing the lowest level) to 10 (representing the highest level). The Government Indicator represents one of the governance indicators used per model (Regulatory_Quality, Rule_of_Law, Voice_Accountability, Political_Stability, Government_Effectiveness, and Control_Corruption), making up a total of 6 models. The model controls for time fixed effects $\theta_{\mathrm{i}}$ and country fixed effects $\theta_{t}$. The cit stands for the error term. we have two control variables and an interaction variable of interest between religiosity and governance as we assume religiosity does depend on governance in a given country. our main 
variables of interest are the governance indicators, the religiosity variables, and the interaction variables.

\section{Results}

Using Income level as our dependent variable, we run the regression with and without introducing government indicators. Breusch Pagan test showed no evidence of heteroskedasticity. As shown in table (3), model (1) of the table presents the results of running the regression without adding any government indicator. Models (2) to (7) adds one government indicator at a time.

Goodness of fit is reported at the end of the table; all R-squared values are higher than .40. As we mentioned in the previous section, we use government indicators as new control variables to test whether including them can change the relationship between religiosity and income. Without including interaction variables in the model, four of the government indicators showed no significant effect on the dependent variable, however, their signs are all positive as expected. The two indicators that showed significance at 10 are Government Effectiveness and Voice Accountability. As predicted, the dummy variable Religious_Or_Not which estimates religiosity shows negative and highly significant effect among all the models included in table (3). Education level and being married had positive and highly significant results in table (3) and (4). The size of the effect of religiosity and being married is very small compared to the effect of education.

As predicted, across all models of table (4), the effect of religiosity on income is small, negative, and highly significant. In table (4) we include the interaction variables between religiosity and each government indicator to check if the negative sign might flip. All R squared values are higher than .40 too. Which is sufficient in behavioral models. Two of the interactions showed significance at .10 and three did not show significance but the five interaction variables showed negative effects. Although insignificant, however, the government effectiveness interaction variable is the only interaction that showed a positive coefficient with a considerable effect size. The R-squared of this model is the highest compared to all models estimated. The p-value of the insignificant interaction is .364 in this model. When religiosity is dependent on government effectiveness, the negative effect of religiosity on income reduces even though the negative effect of religiosity in this model (2) is the highest across all the other models.

To correctly estimate the significance of an interaction term, the model has to be evaluated at different levels. Table (5) presents coefficients of religiosity at different government effectiveness levels.

Government effectiveness index ranges from -2.5 to 2.5 . Starting at the minimum, we add a 0.5 unit each time to reach the maximum in order to test the significance and size at each level. we then divide our scale into 5 main levels. The table clearly shows how the negative effect of religiosity on income drops from -.053 ( $\mathrm{p}=.025)$ to $-.020(\mathrm{p}=.238)$ and becomes insignificant at very high government effectiveness levels.

\section{Discussion}

Using a time and country fixed effects model, we estimated the effect of religiosity on income among Muslims. Consistent with previous literature (Keister \& Lisa 2008; Becker \& Woessmann 2013; Herzer et. al. 2017; Achi et. al. 2010; Lipford \& Robert 2003), religiosity was found to negatively affect income. The contribution of this research is introducing the government in determining the relationship. This research argues that a better version of Islam in the minds of its followers depends on the degree of government effectiveness. Results show that under better government effectiveness levels, the negative effect of religiosity on income decreases until it becomes insignificant. Figure (2) shows the 2018 ranking of the government effectiveness estimates for all muslim majority countries (more than $50 \%$ of the population. As seen from the figure, we expect the negative statistical https://doi.org/10.24035/ijit.20.2021.217 
relationship between religiosity and income to be very low and near insignificance in countries with positive estimates. The top five countries are: United Arab Emirates, Brunei Darussalam, Malaysia, Qatar and Saudi Arabia. We also expect that countries with very low government effectiveness estimates like Comors, Syria, Libya, Somalia and Yemen to have a higher negative impact of religiosity on income, further research is needed.

Figure (2): Government Effectiveness Estimates of Muslim-Majority Countries for the year 2018

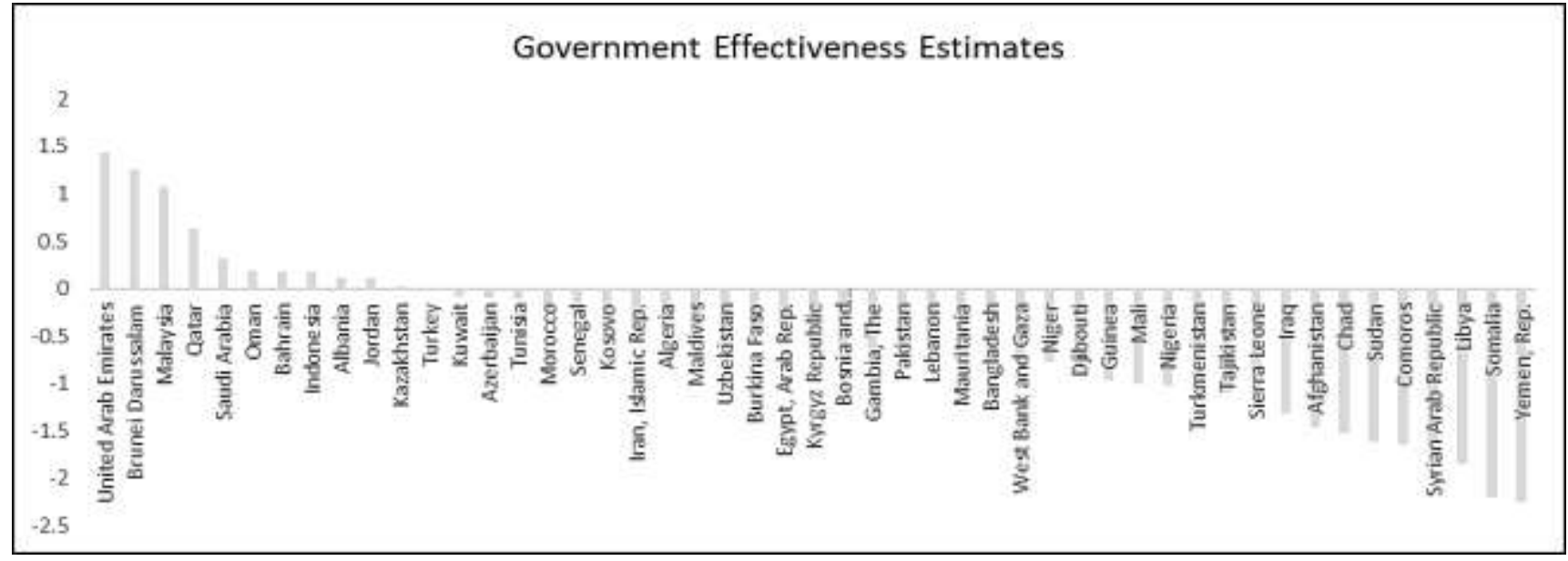

Source: World Governance Indicators - World Bank Database (govdata360.worldbank.org)

According to the world bank, the government effectiveness indicator captures the quality of public services, and the quality of the civil services. We conclude that living in places with higher government effectiveness shapes a better version in the minds of Muslims and hence their religiosity doesn't become an economic obstacle to their economic performance. If the effect is true in the population, countries with better governments should not view religious Muslims as a threat to their economy. In future research, we suggest accounting for reverse causality and adding other potential confounding variables and an index of religiosity. Religion is very subjective and depends on multiple factors, and the power of the interaction variable in flipping the effect draws our attention towards other variables that could also cause this to happen. Our interpretation to most of the previous and relatively recent research in the field of economics of religion might be different in this case.

Table (3): Religiosity Effect on Income level among Muslims Including Governance Indicators

\begin{tabular}{|c|c|c|c|c|c|c|c|}
\hline \multicolumn{8}{|c|}{ Dependent Variable: Income Level } \\
\hline VARIABLES & $\begin{array}{c}(1) \\
\text { Model } 1 \\
\end{array}$ & $\begin{array}{c}2) \\
\text { Model } 2 \\
\end{array}$ & $\begin{array}{c}3) \\
\text { Model } 3 \\
\end{array}$ & $\begin{array}{c}(4) \\
\text { Model } 4 \\
\end{array}$ & $\begin{array}{c}(5) \\
\text { Model } 5 \\
\end{array}$ & $\begin{array}{c}(6) \\
\text { Model } 6 \\
\end{array}$ & $\begin{array}{c}(7) \\
\text { Model } 7 \\
\end{array}$ \\
\hline Education & $\begin{array}{c}0.566^{* * *} \\
(0.174)\end{array}$ & $\begin{array}{c}0.524^{* * *} \\
(0.180)\end{array}$ & $\begin{array}{c}0.503^{* * *} \\
(0.174)\end{array}$ & $\begin{array}{c}0.559^{* * *} \\
(0.175)\end{array}$ & $\begin{array}{c}0.545^{* * *} \\
(0.180)\end{array}$ & $\begin{array}{c}0.549^{* * *} \\
(0.181)\end{array}$ & $\begin{array}{c}0.518^{* * *} \\
(0.172)\end{array}$ \\
\hline Married & $\begin{array}{c}0.0264^{* * *} \\
(0.00774)\end{array}$ & $\begin{array}{c}0.0249 * * * \\
(0.00792)\end{array}$ & $\begin{array}{c}0.0269 * * * \\
(0.00757)\end{array}$ & $\begin{array}{l}0.0265^{* * *} \\
(0.00778)\end{array}$ & $\begin{array}{c}0.0260^{* * *} \\
(0.00784)\end{array}$ & $\begin{array}{l}0.0261^{* * *} \\
(0.00786)\end{array}$ & $\begin{array}{c}0.0245^{* * *} \\
(0.00762)\end{array}$ \\
\hline Religious_Or_Not & $\begin{array}{r}-0.0331^{* * *} \\
(0.00901)\end{array}$ & $\begin{array}{r}-0.0325^{* * *} \\
(0.00904)\end{array}$ & $\begin{array}{r}-0.0341^{* * *} \\
(0.00883)\end{array}$ & $\begin{array}{r}-0.0341^{* * *} \\
(0.00917)\end{array}$ & $\begin{array}{r}-0.0329^{* * *} \\
(0.00909)\end{array}$ & $\begin{array}{r}-0.0330^{* * *} \\
(0.00911)\end{array}$ & $\begin{array}{r}-0.0332^{* * *} \\
(0.00879)\end{array}$ \\
\hline Control_Corruption & & $\begin{array}{c}0.519 \\
(0.537)\end{array}$ & & & & & \\
\hline Govt_Effectivness & & & $1.086^{*}$ & & & & \\
\hline
\end{tabular}




\begin{tabular}{|c|c|c|c|c|c|c|c|}
\hline Political_Stability & & & & $\begin{array}{c}0.500 \\
(0.651)\end{array}$ & & & \\
\hline Regulatory_Quality & & & & & $\begin{array}{c}0.333 \\
(0.620)\end{array}$ & & \\
\hline Rule_of_Law & & & & & & $\begin{array}{c}0.292 \\
(0.741)\end{array}$ & \\
\hline Voice_Accountability & & & & & & & $\begin{array}{l}1.250^{*} \\
(0.692)\end{array}$ \\
\hline Constant & $\begin{array}{c}3.030^{* *} \\
(1.272) \\
\end{array}$ & $\begin{array}{r}3.186^{* *} \\
(1.283) \\
\end{array}$ & $\begin{array}{c}3.049^{* *} \\
(1.243) \\
\end{array}$ & $\begin{array}{c}3.212^{* *} \\
(1.299) \\
\end{array}$ & $\begin{array}{l}.054^{* *} \\
(1.283) \\
\end{array}$ & $\begin{array}{l}3.080^{* *} \\
(1.290) \\
\end{array}$ & $\begin{array}{l}3.229^{* *} \\
(1.244) \\
\end{array}$ \\
\hline Observations & 114 & 114 & 114 & 114 & 114 & 114 & 114 \\
\hline R-squared & 0.431 & 0.444 & 0.469 & 0.439 & 0.435 & 0.434 & 0.472 \\
\hline Number of Countries & 68 & 68 & 68 & 68 & 68 & 68 & 68 \\
\hline
\end{tabular}

Notes:

- Standard errors in parentheses

- $\quad{ }^{* * *} \mathrm{p}<0.01,{ }^{* *} \mathrm{p}<0.05,{ }^{*} \mathrm{p}<0.1$

- Control_Corruption $\mathrm{p}=0.339$

- Govt_Effectivness $\mathrm{p}=0.092$

- Political_Stability $p=0.447$

- Regulatory_Quality $\mathrm{p}=0.594$

- Rule_of_Law p= 0.696

- Voice_Accountability p $=0.078$

Table (4): Religiosity Effect on Income level among Muslims Including Interaction Variables

\begin{tabular}{|c|c|c|c|c|c|c|}
\hline \multicolumn{7}{|c|}{ Dependent Variable: Income Level } \\
\hline & $(1)$ & $(2)$ & $(3)$ & $(4)$ & $(5)$ & $(6)$ \\
\hline VARIABLES & Model 1 & Model 2 & Model 3 & Model 4 & Model 5 & Model 6 \\
\hline Education & $\begin{array}{c}0.521^{* * *} \\
(0.183)\end{array}$ & $\begin{array}{c}0.513^{* * *} \\
(0.175)\end{array}$ & $\begin{array}{c}0.533^{* * *} \\
(0.172)\end{array}$ & $\begin{array}{c}0.541^{* * *} \\
(0.183)\end{array}$ & $\begin{array}{r}0.547^{* * *} \\
(0.184)\end{array}$ & $\begin{array}{r}0.505^{* * *} \\
(0.174)\end{array}$ \\
\hline Married & $\begin{array}{c}0.0248^{* * *} \\
(0.00802)\end{array}$ & $\begin{array}{c}0.0269 * * * \\
(0.00759)\end{array}$ & $\begin{array}{l}0.0259^{* * *} \\
(0.00762)\end{array}$ & $\begin{array}{c}0.0259^{* * *} \\
(0.00796)\end{array}$ & $\begin{array}{c}0.0261^{* * *} \\
(0.00795)\end{array}$ & $\begin{array}{c}0.0246^{* * *} \\
(0.00768)\end{array}$ \\
\hline Religious_Or_Not & $\begin{array}{r}-0.0321^{* * *} \\
(0.00954)\end{array}$ & $\begin{array}{r}-0.0370^{* * *} \\
(0.00941)\end{array}$ & $\begin{array}{r}-0.0326^{* * *} \\
(0.00902)\end{array}$ & $\begin{array}{c}-0.0319^{* * *} \\
(0.0105)\end{array}$ & $\begin{array}{r}-0.0327^{* * *} \\
(0.00985)\end{array}$ & $\begin{array}{r}-0.0304^{* * *} \\
(0.00993)\end{array}$ \\
\hline Control_Corruption & $\begin{array}{c}0.617 \\
(0.848)\end{array}$ & & & & & \\
\hline Interaction_Corruption & $\begin{array}{c}-0.00112 \\
(0.00745)\end{array}$ & & & & & \\
\hline Govt_Effectivness & & $\begin{array}{c}0.725 \\
(0.744)\end{array}$ & & & & \\
\hline Interaction_Effectiveness & & $\begin{array}{c}0.00658 \\
(0.00717)\end{array}$ & & & & \\
\hline Political_Stability & & & $\begin{array}{l}1.908^{*} \\
(1.055)\end{array}$ & & & \\
\hline Interaction_Political & & & $\begin{array}{c}-0.0165 \\
(0.00983)\end{array}$ & & & \\
\hline Regulatory_Quality & & & & $\begin{array}{c}0.492 \\
(1.012)\end{array}$ & & \\
\hline Interaction_Regulatory & & & & -0.00181 & & \\
\hline
\end{tabular}


Rule_of_Law

Interaction_Law

Voice_Accountability

Interaction_Voice

Constant

Observations

R-squared

Number of Countries

\begin{tabular}{|c|c|c|c|c|c|}
\hline & \multicolumn{5}{|c|}{$(0.00905)$} \\
\hline & & & & $\begin{array}{c}0.339 \\
(0.968) \\
-0.000619 \\
(0.00806)\end{array}$ & \\
\hline & & & & & $\begin{array}{c}1.693^{*} \\
(1.005) \\
-0.00593 \\
(0.00967)\end{array}$ \\
\hline $\begin{array}{c}3.170 * * \\
(1.303)\end{array}$ & $\begin{array}{c}3.187^{* *} \\
(1.255)\end{array}$ & $\begin{array}{c}3.259 * * \\
(1.273)\end{array}$ & $\begin{array}{c}2.995^{* *} \\
(1.331)\end{array}$ & $\begin{array}{c}3.066^{* *} \\
(1.319)\end{array}$ & $\begin{array}{c}3.063^{* *} \\
(1.282)\end{array}$ \\
\hline 114 & 114 & 114 & 114 & 114 & 114 \\
\hline 0.444 & 0.480 & 0.475 & 0.436 & 0.434 & 0.477 \\
\hline 68 & 68 & 68 & 68 & 68 & 68 \\
\hline
\end{tabular}

Notes:

- $\quad$ Standard errors in parentheses

- $\quad * * * \mathrm{p}<0.01, * * \mathrm{p}<0.05, * \mathrm{p}<0.1$

- Interaction_Corruption $\mathrm{p}=0.881$

- Interaction_Effectiveness $\mathrm{p}=0.364$

- Interaction_Political $\mathrm{p}=0.102$

- Interaction_Regulatory $\mathrm{p}=0.842$

- Interaction_Law $\mathrm{p}=0.939$

- Interaction_Voice $\mathrm{p}=0.543$

Table (5): The Effect of Religiosity on Income at Different Government Effectiveness Units

\begin{tabular}{|c|c|c|c|c|}
\hline \multicolumn{2}{|c|}{ Government Effectiveness } & \multirow{2}{*}{$\frac{\text { Coef. }}{-.0534447}$} & \multirow{2}{*}{$\frac{\text { Std. Err. }}{.02290814}$} & \multirow{2}{*}{$\frac{\mathrm{P}>\mathrm{t}}{0.025^{* *}}$} \\
\hline Voru I & -2.5 & & & \\
\hline very Low & -2 & -.0501567 & .01965036 & $0.015^{* *}$ \\
\hline \multirow[t]{3}{*}{ Low } & -1.5 & -.04686862 & .01652862 & $0.007^{* * *}$ \\
\hline & -1 & -.04358053 & .01363666 & $0.003^{* * *}$ \\
\hline & -.5 & -.04029245 & .01115466 & $0.001^{* * *}$ \\
\hline \multirow[t]{2}{*}{ Moderate } & $\mathbf{0}$ & .03700436 & .009412725 & $0.000 * * *$ \\
\hline & .5 & -.03371627 & .008858729 & $0.000^{* * *}$ \\
\hline \multirow{2}{*}{ High } & 1 & -.03042819 & .009698431 & $0.003^{* * *}$ \\
\hline & 1.5 & -.0271401 & .01163387 & $0.025^{* *}$ \\
\hline \multirow{2}{*}{ Very High } & 2 & -.02385202 & .01422459 & 0.101 \\
\hline & 2.5 & -.02056393 & .01717661 & 0.238 \\
\hline
\end{tabular}

Notes:

- Government Effectiveness Index range : ( -2.5 to 2.5)

- $\quad * * * \mathrm{p}<0.01,{ }^{* *} \mathrm{p}<0.05,{ }^{*} \mathrm{p}<0.1$ 


\section{References}

Albertsen, Daniel; de Soysa, Indra. 2018. Oil, Islam, and the Middle East: An empirical analysis of the repression of religion, 1980-2013. Politics \& Religion. 11(2): 249-280.

Becker, S. O., \& Woessmann, L. 2013. Not the opium of the people: Income and secularization in a panel of Prussian counties. American Economic Review. 103(3): 539-44.

Bier, D. 2016. Muslims rapidly adopt U.S. social values. Cato Institute Blog. https://www.cato.org/blog/muslims-rapidly-adopt-us-social-political-values. Retrieved: 20 March 2020.

Bobrick, B. 2012. The caliph's splendor: Islam and the West in the Golden Age of Baghdad. Simon and Schuster.

Bowen, R., Baetz, M., \& D'Arcy, C. 2006. Self-rated importance of religion predicts one-year outcome of patients with panic disorder. Depression and Anxiety. 23(5): 266-273

Campante, F., \& Yanagizawa-Drott, D. 201). Does religion affect economic growth and happiness? Evidence from Ramadan. The Quarterly Journal of Economics. 130(2): 615-658.

Furia, P. A., \& Lucas, R. E. 2008. Arab Muslim attitudes toward the West: Cultural, social, and political explanations. International Interactions: 34(2): 186-207.

Guiso, L., Sapienza, P., \& Zingales, L. 2002. People's opium? Religion and economic activities. NBER Working Paper, 9237.

Ali, S. S., \& Hasan, H. 2019. Does religiosity affect multidimensional poverty? Evidence from world values survey (2010-2014). Journal of King Abdulaziz University: Islamic Economics. 32(2): 324.

Herzer, D., \& Strulik, H. 2017. Religiosity and income: A panel cointegration and causality analysis. Applied Economics. 49(30): 2922-2938.

Hilary, G., \& Hui, K. W. 2009. Does religion matter in corporate decision making in America?. Journal of Financial Economics. 93(3): 455-473.

Hillman, A. L., \& Potrafke, N. 2018. Economic freedom and religion: An empirical investigation. Public Finance Review. 46(2): 249-275.

Iannaccone, L. R. 1998. Introduction to the Economics of Religion. Journal of Economic Literature. 36(3): 1465-1495.

Iyer, S. 2016. The new economics of religion. Journal of Economic Literature. 54(2): 395-441.

Joshanloo, M. 2018. Income satisfaction is less predictive of life satisfaction in individuals who believe their lives have meaning or purpose: A 94-nation study. Personality and Individual Differences. 129: 92-94.

Keister, L. A. 2008. Conservative Protestants and wealth: How religion perpetuates asset poverty. American Journal of Sociology. 113(5): 1237-1271.

Langbein, L., \& Knack, S. (2010). The worldwide governance indicators: six, one, or none?. The Journal of Development Studies. 46(2): 350-370.

Lipford, J. W., \& Tollison, R. D. 2003. Religious participation and income. Journal of Economic Behavior \& Organization. 51(2): 249-260.

Guiso, L., Sapienza, P., \& Zingales, L. 2003. People's opium? Religion and economic attitudes. Journal of Monetary Economics. 50(1): 225-282.

Ma, X., Su, Z., \& Huang, J. 2018. Religion, economic attitudes and household savings: Evidence from CGSS (2010). Journal of Interdisciplinary Mathematics. 21(2): 529-537.

Martin, W. T. 1984. Religiosity and United States suicide rates, 1972-1978. Journal of Clinical Psychology. 40(5): 1166-1169.

McCleary, R., \& Barro, R. 2003. Religion and Economic Growth Across Countries. Harvard: Harvard University Department of Economics.

https://doi.org/10.24035/ijit.20.2021.217 
McCleary, R. M., \& Barro, R. J. 2006. Religion and economy. Journal of Economic Perspectives. 20(2): 49-72.

Naveed, A., \& Wang, C. 2018. Can religion explain cross-country differences in inequality? A global perspective. Social Choice and Welfare. 50(3): 481-518.

Norris, P., \& Inglehart, R. F. 2012. Muslim integration into Western cultures: Between origins and destinations. Political Studies. 60(2): 228-251.

Noussair, C. N., Trautmann, S. T., Van de Kuilen, G., \& Vellekoop, N. 2013. Risk aversion and religion. Journal of Risk and Uncertainty. 47(2): 165-183.

Nowrasteh, A. 2016. Muslim Immigration and Integration in the United States and Western Europe. Cato Institute Blog. https://www.cato.org/blog/muslim-immigrationintegration-unitedstates-western-europe. Retrieved: 30 March 2020.

Petrikova, I. 2019. Religion and foreign-policy views: Are religious people more altruistic and/or more militant?. International Political Science Review. 40(4): 535-557.

Vitell, S. J., \& Paolillo, J. G. 2003. Consumer ethics: The role of religiosity. Journal of Business Ethics. 46(2): 151-162.

Welch, P. J., \& Mueller, J. J. 2001. The relationships of religion to economics. Review of Social Economy. 59(2): 185-202.

Yusof, S., Budiman, M. A., \& Mohd Amin, R. 2018. relationship between religiosity and individual economic achievement: evidence from South Kalimantan, Indonesia.Journal of King Abdulaziz University: Islamic Economics. 31(2): 3-16

Zuckerman, M., Li, C., \& Diener, E. 2018. Religion as an exchange system: The interchangeability of God and government in a provider role. Personality and Social Psychology Bulletin. 44(8): 1201-1213. 